Rev. Biol. Neotrop. 8(1):1-14, 2011

\title{
TEM AND LEAF MORPhOANATOMY OF TWO AtLANTIC Forest SPECIES OF SMILAX LINNAEUS
}

\section{Alessandra Ribeiro Guimarães}

Pós-graduação em Botânica, Museu Nacional, Universidade Federal de Rio de Janeiro, Quinta da Boa Vista, s/no, 20940-040, Rio de Janeiro, Rio de Janeiro, Brazil; e-mail: alessandracastellan@gmail.com

\section{Regina Helena Potsch Andreata}

Instituto de Ciências Biológicas e Ambientais, Universidade Santa Úrsula, Rua Fernando Ferrari, 75, 22231-040, Rio de Janeiro, Rio de Janeiro, Brazil

\section{Cecília Gonçalves Costa}

Instituto de Pesquisas Jardim Botânico do Rio de Janeiro, Rua Pacheco Leão, 915, 22460-030, Rio de Janeiro, Rio de Janeiro, Brazil; e-mail: ccosta@jbrj.gov.br

\begin{abstract}
In this work, we analyze the morphoanatomical characteristics of the stem and leaves of Smilax quinquenervia and Smilax subsessiliflora in order to detect aspects that can help identify these species. Specimens were collected in the municipality of Miguel Pereira, Rio de Janeiro, Brazil, and histological slides were prepared according to traditional techniques of plant anatomy. Some anatomic characteristics are common to both species, including raphide and prismatic crystals of calcium oxalate and the occurrence of a sclerenchymatic sheath in the vascular bundles. Other aspects have diagnostic value for the species analyzed: thorns (vascularized emergences) at the nodes, striated cuticle, and cortical vascular bundles appearing as leaf traces in the aerial stem of S. quinquenervia; cork warts in the leaf and groups of palisade cells in the mesophyll of S. quinquenervia; aculei (non-vascularized emergences) at the nodes and internodes, striated cuticle with micropapillae, and a biseriate epidermis in the aerial stem of S. subsessiliflora; presence of groups of lobate cells in the mesophyll of S. subsessiliflora. A comparative table, which points to these aspects and others referenced in the literature for the Smilax species, is provided. The anatomical studies of the two species analyzed provide the basis for their recognition.
\end{abstract}

KEY words: Anatomy, Smilacaceae, Smilax quinquenervia, Smilax subsessiliflora, vegetative axis.

\section{Morfoanatomia de caule e folhas de duas espécies de Smilax Linnaeus da Mata Atlântica}

Resumo: No presente trabalho, são analisadas as características morfoanatômicas do caule e das folhas de Smilax quinquenervia e Smilax subsessiliflora com o objetivo de detectar aspectos que possam auxiliar no reconhecimento destas espécies. Os espécimes foram coletados no município de Miguel Pereira, Rio de Janeiro, Brasil, e as lâminas histológicas foram preparadas de acordo com técnicas usuais em anatomia vegetal. Algumas características anatômicas são comuns às duas espécies, como ráfides e cristais prismáticos de oxalato de cálcio e a ocorrência de uma bainha esclerenquimática circundando os feixes vasculares. Outros aspectos têm valor diagnóstico para as espécies analisadas, a saber: espinhos (emergências vascularizadas) nos nós, cutícula estriada e feixes vasculares corticais que correspondem aos traços foliares no caule aéreo de S. quinquenervia; verrugas suberosas na folha e células paliçádicas em grupos no mesofilo de S. quinquenervia; acúleos (emergências não vascularizadas) nos nós e entrenós, cutícula estriada com micropapilas e epiderme bisseriada no caule aéreo de S. subsessiliflora; grupos de células lobadas no mesofilo de $S$. subsessiliflora. Uma tabela comparativa, que aponta esses aspectos e outros referenciados na literatura para as espécies Smilax, é fornecida. O estudo anatômico dessas duas espécies serve de base para subsidiar seu reconhecimento.

Palavras-chave: Anatomia, Smilacaceae, Smilax quinquenervia, Smilax subsessiliflora, eixo vegetativo. 


\section{INTRODUCTION}

S milacaceae, related to both Philesiaceae and Ripogonaceae (Judd et al., 2009) is distributed mostly in tropical and subtropical regions (Heywood, 1978), and this family is represented in Brazil by 32 species of Smilax L. With 15 exclusive species, southeastern Brazil is the center of genetic diversity of Smilax. These species are widely distributed throughout Brazil and are locally known as "salsaparilha" or "japecanga". Most commonly, they occur in forests, especially in the Atlantic Forest (Andreata, 1997, 2009).

Even though the genus Smilax is taxonomically well defined, it shows great intraspecific variability, which is even manifested in the same individual, most notably in the leaves and aerial stems (Andreata, 1997). Since identifying Smilax species is not always easy, field surveys are indispensable. As several species of Smilax are widely used in folk medicine (Hoehne, 1955; Peckolt, 1936; Silva, 2006), better identification procedures are fundamental to control the quality of raw materials used in phytotherapeutics, resulting in greater user's confidence (Brasil, 2004).

Anatomical studies of this group can provide useful information, which, together with external morphological characteristics, will contribute to resolving taxonomic questions. This, in turn, will generate the funding necessary to elucidate the phylogenetic relationships among species (Judd et al., 2002) based on their separation at different levels (Metcalfe \& Chalk, 1983).

The earliest studies of the anatomy of Smilacaceae (Cunha, 1937; Stellfeld, 1940) focused mainly on the roots, as they are the parts used for medicinal purposes. Caponetti and Quimby (1956) also examined the leaves and stems of five species. Ervin and Evert (1967), in turn, described the phloem of Smilax rotundifolia L., whereas Martin and Tucker (1985) described the stem apices of four species of Smilax. Other researchers concentrated on their underground systems, namely, Oliveira et al. (1973) working with Smilax japecanga Griseb.; Andreata and Menezes (1999) with Smilax quinquenervia Vell.; and, more recently, Guimarães et al. (2010a) with Smilax subsessiliflora Duham. Previously, Guimarães et al. (2010b), on a scientific initiation approach, have studied the leaf anatomy of three species of the genus: $S$. quinquenervia Vell., S. subsessiliflora Duham, and Smilax stenophylla DC. However, considering the pharmacological interest of the two first species, an in-depth analysis was conducted on the vegetative organs of these species.

According to Andreata (1997), Brazilian species of the genus are dioecious, most are vines, and a few are sub-shrub and shrub species. The underground systems of these species generally present thickened woody stem, from which adventitious roots and cylindrical or angular aerial shoots originate, almost always with aculei or thorns. The leaves are simple, alternate, with leaf sheaths and a pair of petiolar tendrils. The inflorescences are umbelliform cymes, and the fruits are berries with zoochoric dispersal.

In light of the known morphological variability of Smilax species, the present study describes the morphoanatomy of the stems and leaves of S. quinquenervia Vell. and S. subsessiliflora Duham. in order to identify anatomical characters useful for their circumscription.

\section{MATERIALS AND METHOdS}

The specimens analyzed in the present work were collected in a fragment of the Atlantic Forest in the municipality of Miguel Pereira, Rio de Janeiro, Brazil. The species were identified by Dr. Regina H. Potsch Andreata. The vouchers were deposited in the herbarium of the Instituto de Pesquisas Jardim Botânico do Rio de Janeiro: S. quinquenervia: A. O. Dias Neto s.n. (RB 468830); S. subsessiliflora: A. O. Dias Neto 47, 48, 51 (RB), with duplicates in the herbarium of the Universidade Santa Ursula (RUSU).

The anatomical study was based on samples collected from three adult individuals. The stem was analyzed at the apex, in the third and 12th internodal regions, and in its underground portion. Studies of the mature, fully expanded leaf included the leaf blade (central vein, intercostal area, and the edge), petiole (proximal, median, and distal regions), leaf sheath, and tendrils. 
The material was fixed in FAA in $50 \%$ ethanol and preserved in $70 \%$ ethanol (Johansen, 1940). Samples of the leaves and aerial stems (apical and third internode regions) were embedded in historesin follow-

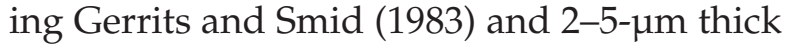
sections were cut using a Jung rotary microtome and subsequently stained with toluidine blue (Sakai, 1973). The stem material from the 12th internode and the underground region was embedded in polyethylene glycol (PEG) 1500 , sectioned with a sliding microtome at an average thickness of $20 \mu \mathrm{m}$, and stained with safranin and astra blue (Bukatsch, 1972).

The leaf epidermis was analyzed in fragments dissociated using the method described by Jeffrey (Johansen, 1940) and subsequently stained with safranin (Bukatsch, 1972).

For scanning electron microscopy (SEM), fragments of the leaf blade (intercostal area) and the aerial stems were fixed in 50\% FAA (Johansen, 1940). This material was subsequently dehydrated in an ascending ethanol series, submitted to $\mathrm{CO}_{2}$ critical point (Horridge $\&$ Tamm, 1969), mounted on aluminum pegs, and coated with a $30 \mathrm{~nm}$ to $40 \mathrm{~nm}$ layer of gold. The epicuticular ornamentation was classified according to Metcalfe and Chalk (1979) and Guaglianone and Gattuso (1991).

The vessel elements were analyzed in material dissociated in Franklin solution (Johansen, 1940) for $72 \mathrm{~h}$, stained with $1 \%$ aqueous safranin, and subsequently mounted with $50 \%$ glycerin as semi-permanent slides (Strasburger, 1924).

Fresh material was used for histochemical tests in order to detect the presence of lignin, using phloroglucinol in acidic media (Johansen, 1940), as well as fluorescence, using auramine (Considine \& Knox, 1979). The composition of the raphide crystals was tested using hydrochloric acid and microscopic observation under polarized light; phenolic compounds were detected using nitrous reaction, according to Jensen (1962).

The morphology of the vegetative organs was documented by digital images taken with a Canon camera. Anatomical details were recorded using a Cool Snap Pro digital camera coupled to an Olympus BX 50 microscope and processed using Image Pro-
Plus version 4.0 software for Windows. The SEM images were obtained using a Zeiss Evo 40 apparatus.

\section{Results}

In both species, the stem arises from the rhyzophore, with some shoots initially growing in a positive geotropic direction, but later assuming a negative geotropic orientation. The underground portion of the stem is similar to the aerial portion in having nodes, internodes, and cataphylls (Figure 1A), but it has no thorns or aculei.

The aerial portion of the stem of S. quinquenervia is woody, cylindrical, dark green, striated, with robust thorns in the nodal region (Figure 1B). On the other hand, S. subsessiliflo$r a$ has a subangular stem, light green, with a rough surface, and with aculei in the region of the nodes and internodes (Figure 1C).

Both species, S. quinquenervia and S. subsessiliflora, have complete leaves, with a leaf sheath and a pair of petiolar tendrils. The leaf blade of $S$. quinquenervia is dark-green, ovate or lanceolate, with rounded base, sharp apex, and leathery consistency. The leaf blade of $S$. subsessiliflora is light-green, sometimes with whitish spots, ovate-lanceolate or lanceolate, with subcordate or rounded base and sharp apex, and papyraceous or membranous consistency. Aculei are found on the leaf margins, on the midvein, between the petiole and the leaf sheath, and on the abaxial face of the leaf. The leaf vein pattern is acrodromous in both species, of basal origin, with five main veins, and thicker midvein than the first pair of lateral veins.

Smilax subsessiliflora is hypostomatic, while $S$. quinquenervia is hypoamphystomatic, with rare atypical stomata on the adaxial face, with paracytic and anomocytic stomata; S. quinquenervia also has contiguous stomata (Figure 1D). The epidermal cells of both species have anticlinal, straight or curved cell walls in frontal view, generally thicker on the adaxial face. The cuticle surface is rugosemicrotuberculate in S. quinquenervia, especially on the abaxial face (Figure 1E); the epicuticular ornamentation in S. subsessiliflora is composed of grooves or channels, which are more conspicuous on the abaxial face (Figure 1F). 

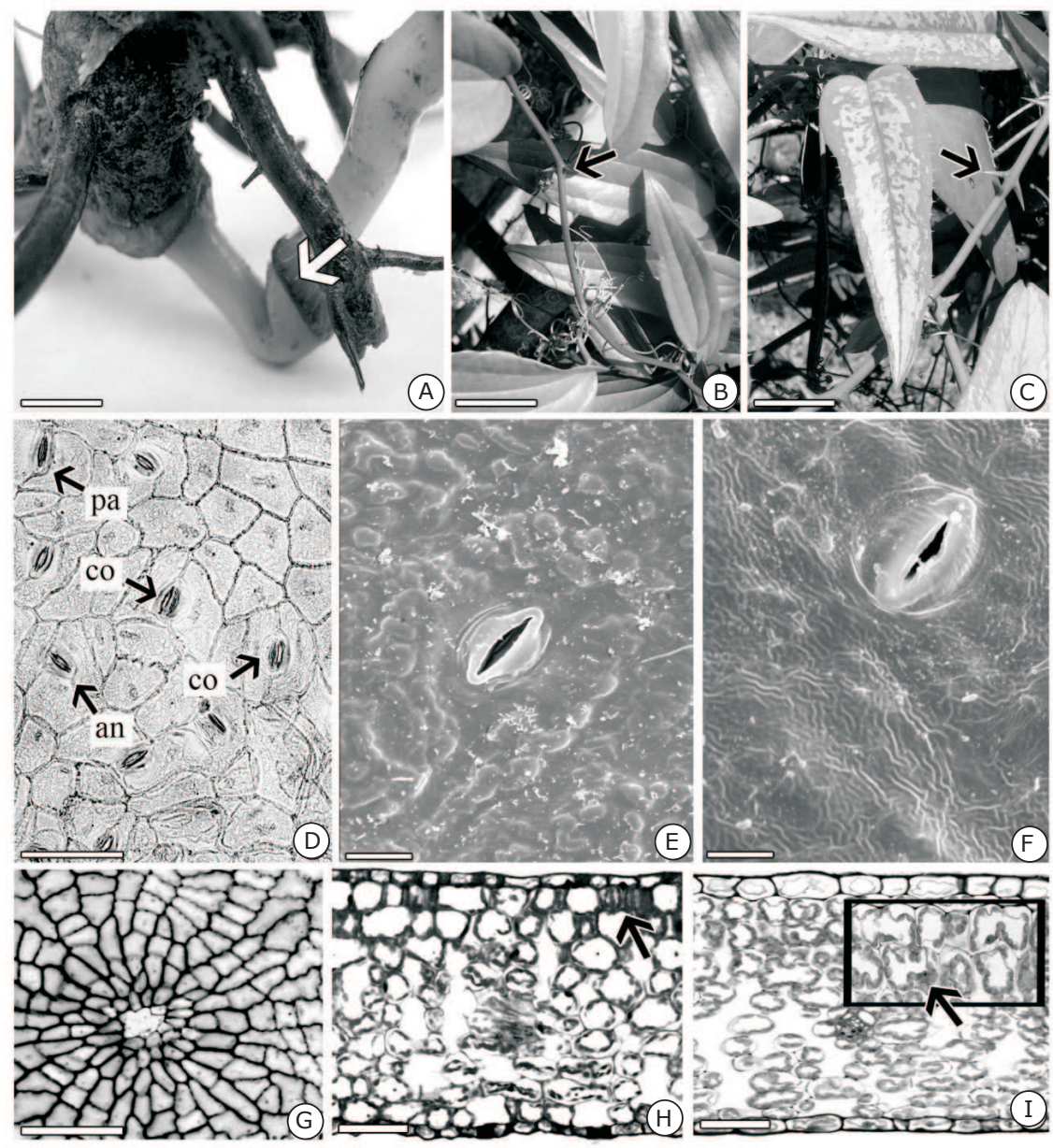

Figure 1 - A. Underground stem of Smilax subsessiliflora. Observe the positive/negative geotropism and the cataphyll (arrow). B. Aerial stem of Smilax quinquenervia, with thorns in the nodal region. C. Aerial stem of Smilax subsessiliflora with aculei in the nodal and internodal regions. D. Epidermis (frontal view OM - abaxial face). Smilax quinquenervia: stomatal patterns. (E-F): Epidermis (frontal view SEM - abaxial face). E. Smilax quinquenervia - rugose microtuberculate epicuticular relief. F. Smilax subsessiliflora - striated epicuticular relief. G. Epidermis (frontal view OM - adaxial face). Smilax quinquenervia: cork wart. (H-I): Leaf blade - mesophyll (TS). H. Smilax quinquenervia - detail: cell group with palisade arrangement. I. Smilax subsessiliflora - detail - lobate cells. OM = optical microscopy; SEM = scanning electron microscopy; TS = transversal section; pa = paracytic; an = anisocytic; co = contiguous. Scales: $1 \mathrm{~cm}(\mathbf{A}, \mathbf{B}, \mathbf{C})$; $10 \mu \mathrm{m}(\mathbf{E}, \mathbf{F}) ; 25 \mu \mathrm{m}(\mathbf{G}) ; 50 \mu \mathrm{m}(\mathbf{D}, \mathbf{H}, \mathbf{I})$.

Smilax quinquenervia has cork warts dispersed on the leaf surface (most frequently on the adaxial face; Figure 1G) at the same level as the other epidermal cells. These structures are represented by a group of cells arranged radially around another group of cells with thin walls (or anomalous stomata) on both faces of the leaf blade.

The leaf blade epidermis is unistratified in both species, with a thick cuticle on the adaxial face and a thin cuticle on the abaxial side. Although the mesophyll does not have typical palisade cells, there is a notorious tendency towards heterogeneity. Under the adaxial epidermis of $S$. quinquenervia, there are 2-4 layers of quadrangular or rectangular cells, and some groups of cells in palisade arrange in the first layer, while S. subsessiliflora has 2-4 layers of lobed parenchyma cells. The spongy parenchyma in both species has irregularly shaped cells distributed in 6-8 layers with conspicuous intracellular spaces (Figure 1H, Figure 1I). The vascular system is represented by small vascular bundles, with sclerenchymatic sheath scattered throughout the mesophyll, where crystalliferous idioblasts with raphides are observed.

The midrib, in transversal view, is markedly convex on the abaxial face of $S$. quinquenervia leaves, but almost plano-convex 
in S. subsessiliflora (Figure 2A, Figure 2B). The epidermis is uniseriate on both faces, with convex periclinal cell walls, and a thick cuticle ornamented on the abaxial face. S. quinquenervia has 4-5 layers of chlorophyllous cells subjacent to the adaxial surface and 2-3 layers of angular collenchyma on the opposite side. The vascular system has three large bundles intercalated with three or four smaller bundles, all of which are accompanied by a sheath of sclerenchyma fibers, with a greater number of layers next to the xylem and phloem. In S. subsessiliflora, the chlorophyllous parenchyma occurs just above the adaxial epidermis and is composed of 2-3 layers of lobate cells. The vascular system is composed of three collateral bundles arranged

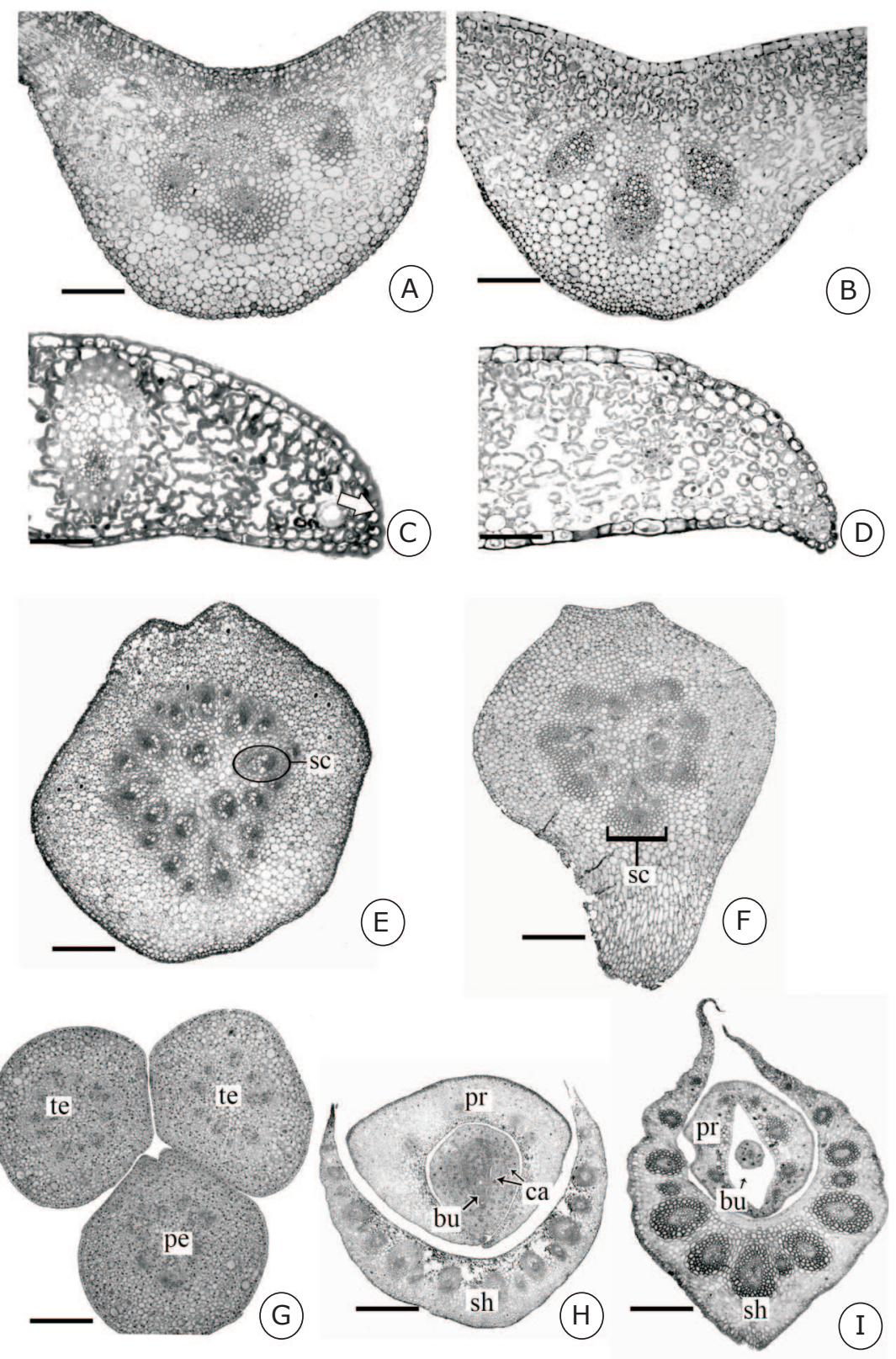

Figure 2 - (A-B): Middle vein (TS). A. Smilax quinquenervia - outline of the abaxial face with accentuated convexity. B. Smilax subsessiliflora - outline plano-convex. (C-D): Leaf margin (TS). C. Smilax quinquenervia - flat with conspicuous cuticular flanges. D. Smilax subsessiliflora - flexed downward. (E-F): Petiole (median region - TS). E. Smilax quinquenervia - collateral vascular bundles with a sclerenchymatic sheath. F. Smilax subsessiliflora - collateral vascular bundles, fibers more abundant near the phloem. G. Petiole (proximal region - TS) of Smilax subsessiliflora observe the tendrils. (H-I): Leaf sheath (TS). H. Smilax quinquenervia - prophylls and two cataphylls surrounding the axilar bud. I. Smilax subsessiliflora - prophyll surrounding the axilar bud. TS = transversal section; sc = sclerenchyma; te $=$ tendrils; pe = petiole; $\mathrm{pr}=$ prophyll; $\mathrm{ca}=$ cataphyll; bu = bud; sh = leaf sheath. Scale: $50 \mu \mathrm{m}$. 
in an arc, accompanied by a sclerenchymatous sheath with the same characteristics as observed in S. quinquenervia (Figure 2A, Figure 2B).

The leaf edge is straight in $S$. quinquenervia (Figure $2 \mathrm{C}$ ), but flexed in the direction of the abaxial face in S. subsessiliflora (Figure 2D). The epidermal cells are smaller along the leaf edges in both species, with convex external periclinal cell walls and thick, ornamented cuticles. Cuticular flanges are most conspicuous in S. quinquenervia (Figure 2C).

In both species, the external morphology of the petiole shows lateral projections that are more pronounced in the proximal and distal regions on the adaxial face (Figure 2E, Figure $2 \mathrm{~F})$. The cortex of $S$. quinquenervia is composed of 1-2 layers of angular collenchyma followed by 12-14 layers of chlorophyllous parenchyma, while the cortex of $S$. subsessiliflora has 6-8 layers. The placement of the vascular bundles accompanies the outline of the petiole, with more than 20 bundles in S. quinquenervia and 10-15 in S. subsessiliflora. The collateral vascular bundles are accompanied by sheaths of sclerenchyma fibers that are more conspicuous in $S$. quinquenervia (Figure 2E); these fibers are more abundant near the phloem in S. subsessiliflora (Figure2F), where there are some medullary bundles, and the parenchymatous cells in this region have thick cell walls. Prismatic crystals and calcium oxalate raphides occur throughout the petiole.

Anatomically, the tendrils are similar to the petiole (Figure 2G, Figure 2H, Figure 2I). Sequential sections revealed that the tendrils arise in the proximal region of the petiole.

In a general manner, the structural characteristics of the leaf sheath in both species are similar to those of the petiole. However, the vascular bundles of the leaf sheath are surrounded by sclerenchymatous sheaths with greater numbers of layers (Figure $2 \mathrm{H}$, Figure 2I).

Longitudinal sections showed the apical meristem with a biseriate tunica-corpus, and the corpus region is subjacent to it, with cells dividing in various planes (Figure 3A). Even during the initial stages of development, it is possible to identify numerous crystalliferous idioblasts containing raphides (Figure 3B).
Transversal sections at the level of the third internode of the aerial stem of $S$. quinquenervia have a uniseriate epidermis composed of cells with rectangular outlines, thin walls and cuticle (Figure 3C). The epidermis of $S$. subsessiliflora is biseriate and arises from periclinal divisions of the first protodermal layer (Figure 3D). The cortex of S. quinquenervia consists of 12-14 layers of lacunar collenchyma, while in S. subsessiliflora, it consists of 10-12 layers of parenchymatic cells. The vascular cylinder is composed of parenchymatic cells, with randomly distributed vascular bundles. Raphide idioblasts occur throughout the organ, being more numerous in the cortical region, especially in the first subepidermal layers in S. subsessiliflora. A strip of periclinally arranged cells still in meristematic phase - primary thickening meristem (PTM), was observed in the region near the vascular cylinder of S. quinquenervia, with vascular bundles in their initial stages of development. These cells are the precursors of the sclerenchymatic sheath, which surrounds the vascular cylinder in later developmental stages (Figure 3E). At the same level (third internode), the protoxylem vessel elements already exhibit secondary parietal thickening, while the vessel elements of the metaxylem still have protoplasmic remains. In the protophloem, some phloem elements are still in the process of differentiation (Figure 3F).

At the level of the 12th internode (frontal view), the stem reaches its full development. Under SEM, the stem surface of S. quinquenervia exhibits epicuticular plates, and in $S$. subsessiliflora, there are epicuticular thin striations and micropapillae (Figure 3G, Figure $3 \mathrm{H})$.

Vascularized outgrowths (thorns) were observed in the nodal region of $S$. quinquenerv$i a$, and non-vascularized outgrowths (aculei) were present in the nodes and internodes in $S$. subsessiliflora (Figure 4A, Figure 4B).

In both species, the stem cortex consists of cells with bars of parietal thickening in which lignification was confirmed by histochemical tests and fluorescence microscopy (Figure 4A, Figure 4B). The cortical region of $S$. quinquenervia has some smaller vascular bundles which correspond to the leaf traces 


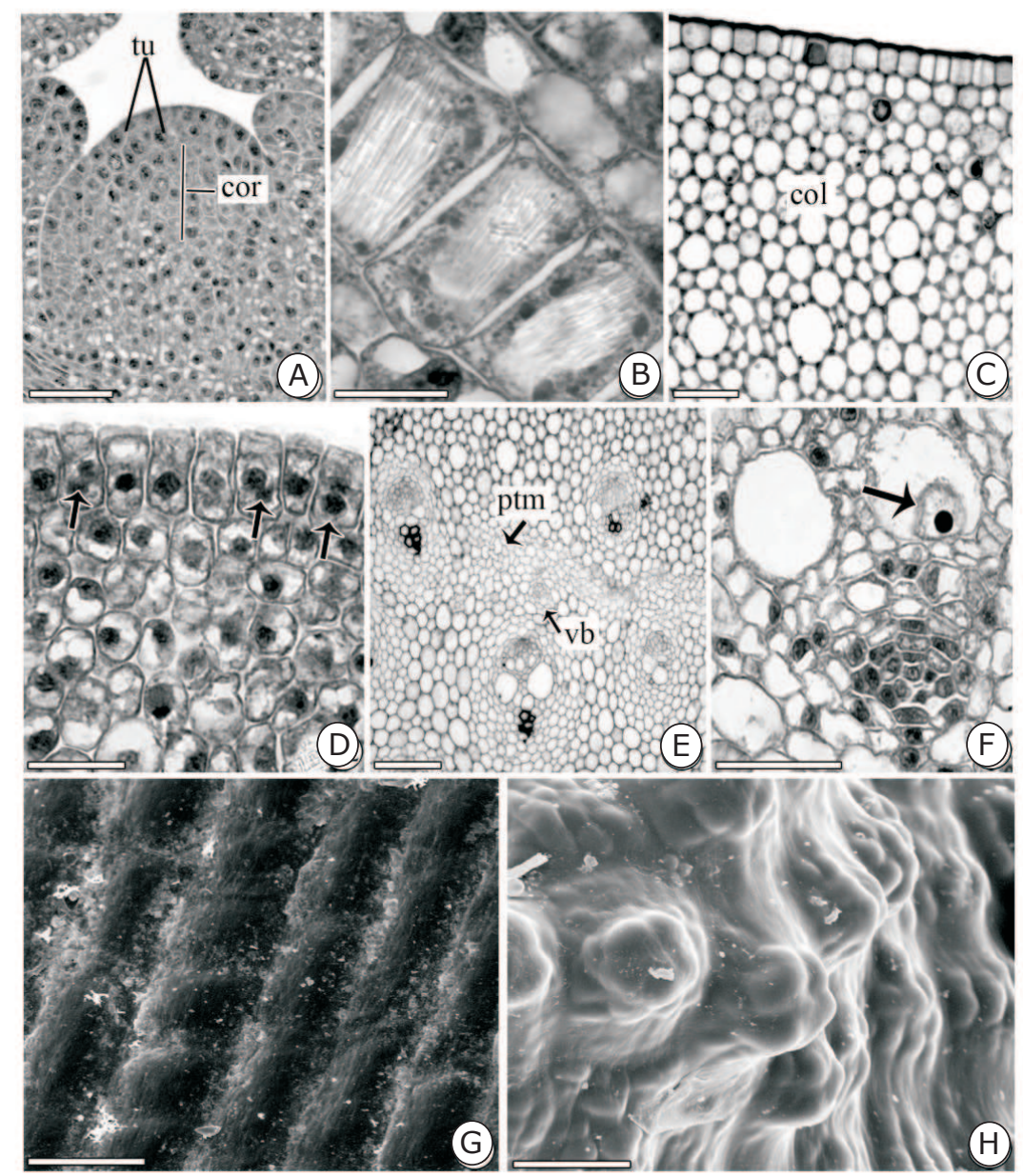

Figure 3 - (A-B): Stem apex of Smilax subsessiliflora (LS). A. Tunica with two cell layers and the corpus. B. Raphides of calcium oxalate. (C-F): Third stem internode (TS). C. Smilax quinquenervia - Uniseriate epidermis and cortex with layers of lacunar collenchyma. D. Smilax subsessiliflora - periclinal divisions in the first layer of protodermal cells (arrow). E. Smilax quinquenervia - primary meristematic thickening and vascular bundles in initial stages of development. F. Smilax subsessiliflora - protoplasmic remains in the vessel elements. (G-H): Twelfth internode (front view - SEM). G. Smilax quinquenervia - epicuticular striations. H. Smilax subsessiliflora - epicuticular striations and micropapillae (arrow). SEM = scanning electron microscopy; TS = transversal section; LS = longitudinal section; tu = tunica; cor = corpus; $c o l=$ collenchyma; $\mathrm{ptm}=$ primary thickening meristem; $v \mathrm{~b}=$ vascular bundle. Scales: $10 \mu \mathrm{m}$ (G, H); $25 \mu \mathrm{m}(\mathbf{A}, \mathbf{B}, \mathbf{D}, \mathbf{F}) ; 50 \mu \mathrm{m}(\mathbf{C}, \mathbf{E})$.

(Figure 4A). Layers of sclerenchymatic fibers with lignified walls, either continuous or interrupted by leaf traces, delimit the vascular cylinders in both species (Figure 4C).

The collateral bundles of the vascular system are surrounded by a sclerenchymatic sheath in which the numbers of layers and thicknesses of walls are variable (Figure 4C, Figure 4D). The bundles are composed of tracheids and vessel elements whose length is also variable. The longest vessel elements (length > $4 \mu \mathrm{m}$; diameter $60 \mu \mathrm{m}$ ) have scalariform parietal thickening and scalariform perforation plates (Figure 4E) and they are predominant in S. quinquenervia. The shortest vessel elements (length $57 \mu \mathrm{m}$; diameter $18 \mu \mathrm{m}$ ) have simple perforation plates and very small pits and they occur more frequently in $S$. subsessiliflora. In the phloem, the perforated tube elements have composite perforation plates in both species.

In several aspects, the underground stems of both species are anatomically similar to the aerial stems, although they can be readily distinguished by the following characteristics: absence of the sclerenchymatic layers that delimit the cortex of the vascular cylinder in aerial stems and presence of a thick sheath with greater numbers of sclerenchyma layers around the vascular bundles (Figure $4 \mathrm{~F}$ ). In $S$. 

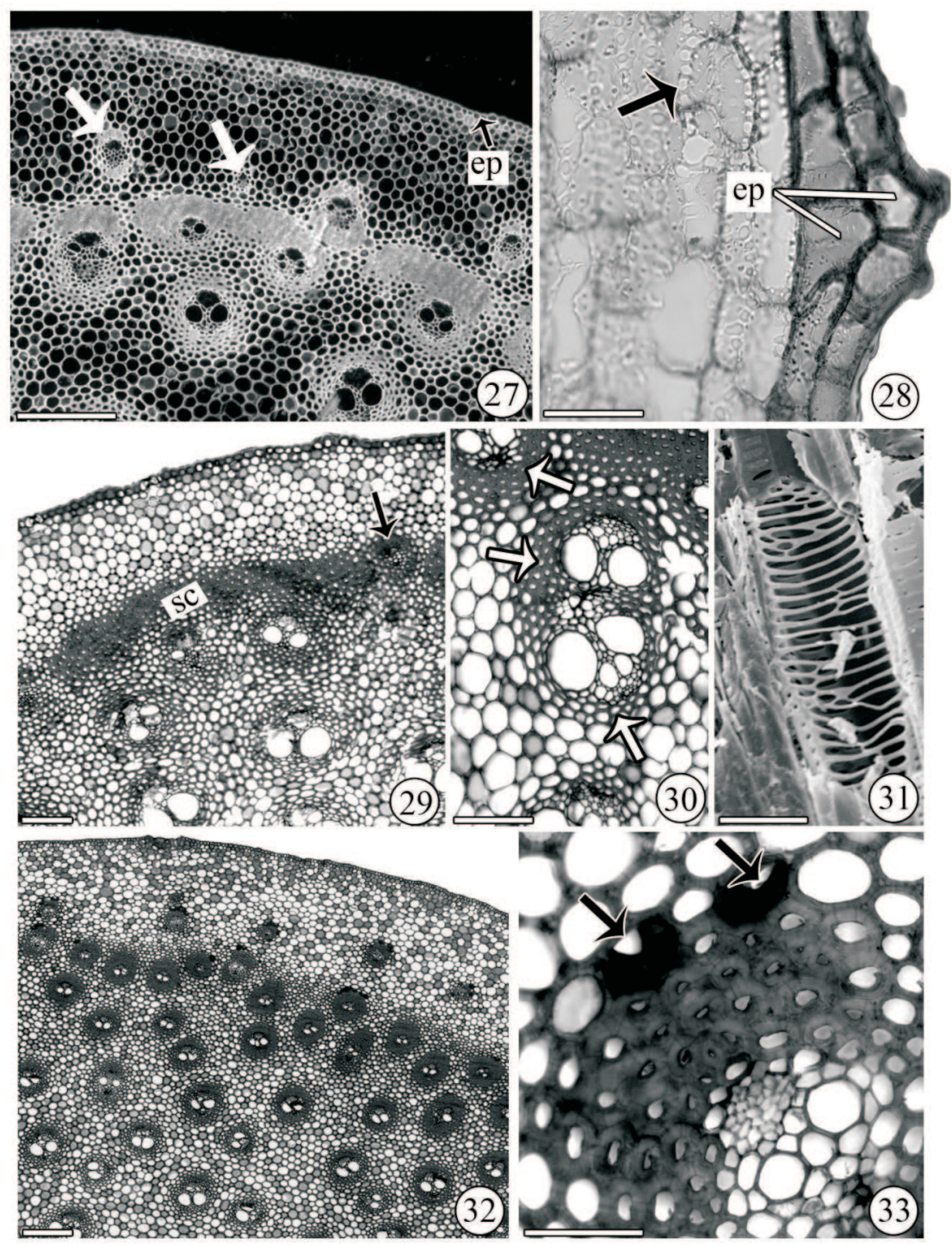

Figure 4 - (A-D): Twelfth stem internode (TS). A. Smilax quinquenervia - epidermal cells and cortical region, with small bundles (arrows). B. Smilax subsessiliflora - biseriate epidermis with papilla in the first layer, parietal thickening (arrow) at the cortical cells. C. Smilax subsessiliflora - sclerenchyma layers interrupted by departure of leaf traces (arrows). D. Smilax quinquenervia - collateral vascular bundles with sclerenchymatic sheath (arrows). E. Smilax subsessiliflora (SEM) - vessel element with scalariform perforation plate. (F-G): Underground stem (TS). F. Smilax quinquenervia - general aspect. G. Smilax quinquenervia - detail: sclereids with thickenings in " $U$ ". SEM = scanning electron microscopy; TS = transversal section; ep = epidermis; sc=sclerenchymatic layer. Scales: $10 \mu \mathrm{m}(\mathbf{E}) ; 25 \mu \mathrm{m}$ (A, B, D, G); $50 \mu \mathrm{m}$ (C); $100 \mu \mathrm{m}$ (F).

quinquenervia, some sclereids with U-shaped thickenings represent remaining endoderm cells of the root, which are observed in the sheaths of the cortical vascular bundles and in the sheaths situated at the periphery of the vascular cylinder (Figure 4G). In S. subsessiliflora, some vascular bundles are essentially composed of fibers.

Histochemical tests revealed the presence of phenolic idioblasts around the vegetative axis in both species.
In Table 1, the anatomical characteristics with diagnostic value for the analyzed species are compared with data extrapolated from the literature about the genus Smilax.

\section{Discussion}

Smilax quinquenervia presents roughmicrotuberculate epicuticular ornamentation of the leaf blade, a pattern also observed by 


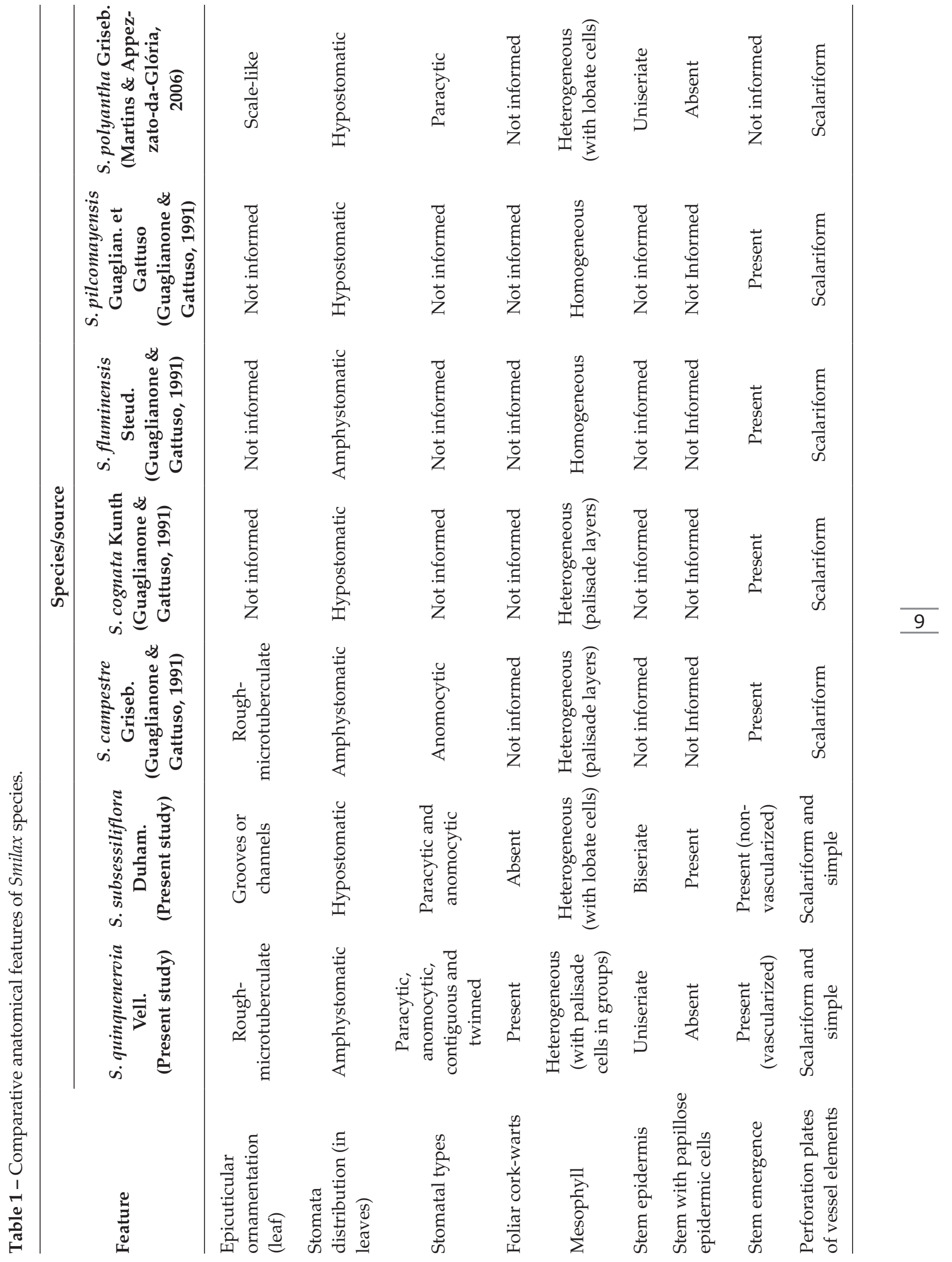


Guaglianone and Gattuso (1991) in Smilax campestris. Martins and Appezzato-da-Glória (2006) reported the occurrence of scale-like epicuticular ornamentations in Smilax polyantha, an aspect not observed in the analyzed species of the present study. According to Fontenelle et al. (1994), the epicuticular ornamentation could be used as an additional taxonomic character. In the particular case of the species under study, this character was also considered to be diagnostically useful.

There is still no consensus among specialists about the origin and morphology of cork warts (Haberlandt, 1928; Metcalfe \& Chalk, 1950; Morretes \& Venturelli, 1985; Solereder, 1908). Authors such as Stace (1965) and Joffily and Vieira $(2005,2010)$ attributed taxonomic value to the cork warts found on leaves because they were observed to be constant in the species they studied. Morretes and Venturelli (1985) observed similar structures on the leaves of a Loranthaceae and called them "lenticels". These authors discussed the ontogeny of these structures and justified their choice of the term "lenticel". Baas (1975) pointed out that some leaves have traumatized areas that have become suberized and, as such, are difficult to distinguish from cork warts. The structures on the leaves of S. quinquenervia do appear to be cork warts; therefore, we adopted this terminology, even though detailed studies were not undertaken to determine their origin. There are no published accounts of the occurrence of these structures in other species of Smilax, and they therefore represent a valuable character for separating $S$. quinquenervia from S. subsessiliflora.

The mesophylls of both species appeared to be dorsiventral by the presence of sparse groups of cells with typical palisade arrangements in S. quinquenervia and lobate cells in the region corresponding to the palisade parenchyma in S. subsessiliflora. Martins and Appezzato-da-Glória (2006) also identified a dorsiventral tendency in the leaves of $S$. polyantha (as judged by the presence of lobate cells in the same region) and stated that it was the first time these types of cells had been seen in any Smilax species.

The vascular systems of $S$. quinquenervia and $S$. subsessiliflora have central veins consisting of collateral bundles, accompanied by a sclerenchyma sheath. A similar situation was described by Marquete and Pontes (1994) for Smilax fluminensis, Smilax rufescens and Smilax spicata. Guaglianone and Gattuso (1991), however, noted only a single sheath surrounding the vascular bundles of Smilax cognata and S. campestris. In terms of the species analyzed here, there were variations in the numbers of vascular bundles, but these were always greater in S. quinquenervia.

Prismatic crystalliferous idioblasts and raphides composed of calcium oxalate were observed in all of the organs of S. quinquenervia and S. subsessiliflora. According to Prychid and Rudall (1999), many monocotyledons contain calcium oxalate crystals, and the presence or absence of different types can constitute taxonomically useful characters. On the other hand, the same authors observed that the role of calcium oxalate crystals in the growth and development of these plants is poorly understood (and probably variable) and may be related to defenses against herbivory and/ or linked to ionic equilibrium. As these structures are constant in both species, they could not be used diagnostically.

Andreata (1997) agreed with Arber (1920) and Martins and Appezzato-da-Glória (2006) about the petiolar origin of tendrils in species of Smilax. The present study corroborated the ideas of these authors in that a similar origin was attributed to the tendrils in both S. quinquenervia and S. subsessiliflora.

The stem apices of both species studied here have two tunica layers. Martin and Turcker (1985) noted the same structural pattern in the apical stem of three other species (Smilax bona-nox, Smilax pumila, and Smilax rotundifolia) and reported that the tunica could have 2-4 cell layers in Smilax laurifolia. The first development phases in the entire apical region of $S$. quinquenervia and $S$. subsessiliflora show the formation of idioblasts with calcium oxalate raphides, as was also noted by Martin and Turcker (1985) in the species they studied.

A uniseriate epidermis was observed in the third stem internode of $S$. quinquenervia, as also reported for the stem of $S$. polyantha by Martins and Appezzato-da-Glória (2006). These authors also mentioned the occurrence 
of a hypodermic layer that was not seen in the species analyzed here. We did note, however, the existence of a biseriate epidermis in S. subsessiliflora in which the first layer was integrated by papilose cells, a feature which apparently has not been reported previously.

According to Esau (1977), the thick stems of some monocotyledons result from the activity of a PTM that is located near the vascular cylinder. DeMason (1980) and Rudall (1991) made similar observations about the location and function of the PTM, which were corroborated by Martins and Appezzato-daGlória (2006) in their analyses of S. polyantha. Guimarães et al. (2010a), in turn, established the same criteria with respect to the underground stem of $S$. subssessiliflora and agreed with Menezes et al. (2005), who considered the PTM to be the pericycle that had resumed its meristematic capacity. An almost continuous layer of cells in the third internode, between the cortex and the vascular cylinder, was identified in S. quinquenervia as being the PTM. This aspect was not seen in the same stem region in S. subssessiliflora, which indicates that stem differentiation occurs differently in the two species.

At the 12th internode, the stem surface was striated in both species, but in S. subsessiliflora, projections and micropapillae also occur.

Bands of sclerenchyma fibers in positions corresponding to the PTM were observed at the 12th internode in the same position as those seen at the third internode. These bands can be continuous or interrupted (especially in S. subsessiliflora), or even absent in the underground portion of the aerial stem in both species. In a study concerning the definition and function of the primary thickening meristem in monocotyledons, DeMason (1983) reported that after the plant had attained its full height and thickness, some cells in the PTM could still maintain their capacity to grow and produce new cells, allowing the stem to grow longer. The author termed this phenomenon the "growth maintenance" stage, during which there was no additional increase in the diameter of this organ. In light of the results presented by DeMason (1983) and our observations of the two species analyzed here, it appears that the layer of sclerenchyma fibers mentioned above was established after the growth maintenance phase of that organ. Additional ontogenetic studies will still be necessary, however, to better define this situation.

The taxonomic revision of the Brazilian species of Smilax by Andreata (1997) mentioned the presence of aculei on the stems of the species of this genus. In the species analyzed herein, these structures consist of epidermal and subepidermal cells and were considered outgrowths, according to the concepts of Uphof (1962), Fahn (1978) and Evert (2006). These outgrowths were vascularized in S. quinquenervia, but not in S. subsessiliflora. Font Quer (1985) considered vascularized outgrowths as "spines", while "prickles" were non-vascularized. Additional studies will be needed with other species of Smilax also having these structures in order to better understand their nature.

The underground portion of the aerial stem of $S$. quinquenervia has sparse sclereids (with U-shaped thickenings) situated externally to the sclerenchymatic sheaths of the cortical bundles, as well as to the bundles that are located at the periphery of the vascular cylinder. It is thought that these sclereids are the remains of endodermal cells, a supposition based on the observation of Van Fleet (1942) concerning the presence of an endoderm in the underground portions of the stems of Smilax species. This author reported the absence of any endoderm in the aerial stem portions of the studied species. Meyer (1881 apud Van Fleet, 1942) also noted a discontinuous endoderm in the stems of several Smilax species.

Vessel elements with scalariform perforation plates were seen in both species analyzed, but $S$. quinquenervia also had vessel elements with simple perforation plates. The former condition was also reported by Cheadle (1942), in five other species of Smilax, and by Martins and Appezzato-da-Glória (2006) in S. polyantha.

The perforated tube elements in the studied species have compound sieve plates in their oblique walls, a condition also reported for perforated tube elements in S. polyantha by Martins and Appezzato-da-Glória (2006). Those authors mentioned that Ervin and 
Evert (1967) observed perforated tube elements with simple or transversal perforated plates in S. rotundifolia, as well as compound and oblique perforated plates. Martins and Appezzato-da-Glória (2006) believed that these characteristics could be useful to distinguish between the species; however, since the patterns of perforated plates were very similar in both S. quinquenervia and S. subsessiliflora, this criterion cannot be used for taxonomic purposes.

The present work indicated various anatomical characters with diagnostic value for the species analyzed, and these are synthesized in Table 1. Some of the features examined here were reported for the first time for the genus Smilax: the presence or absence of vascularization in the stem outgrowths; the occurrence of cork warts on the leaf epidermis; and biseriate stem epidermis. Further studies are required to confirm the occurrence of these characteristics in other species of Smilax.

\section{ACKnowledgements}

The authors thank: CAPES for the Master's grant to the first author; $\mathrm{CNPq}$ for the Research Productivity grants awarded to the other authors and the financial assistance to Regina Potsch Andreata (Proc. 473850/2006-0); the Instituto de Pesquisas Jardim Botânico do Rio de Janeiro for the use of its laboratory facilities and the assistance provided by its technicians; Mr. David Martin for the revision of the text in English; finally, Prof. Ruy J. Válka Alves of the Museu Nacional do Rio de Janeiro for his useful suggestions.

\section{References}

Andreata, R. H. P. 2009. A new species of Smilax and a key to all species from Minas Gerais, Brazil. Syst. Bot. 34: 28-31.

Andreata, R. H. P. 1997. Revisão das espécies brasileiras do gênero Smilax Linnaeus (Smilacaceae). Pesq. Bot. 47: 7-244.

Andreata, R. H. P. \& N. L. Menezes. 1999. Morfoanatomia do embrião, desenvolvimento pós-seminal e origem do rizóforo de Smilax quinquenervia Vell. Bol. Bot. Univ. S. Paulo 18: 39-51.
Arber, A. 1920. Tendrils of Smilax. Bot. Gaz. 69: 438-442.

Baas, P. 1975. Vegetative anatomy and the affinities of Aquifoliaceae, Sphenostemon, Phelline and Oncotheca. Blumea 22: 311407.

Brasil. Ministério da Saúde. Agência Nacional de Vigilância Sanitária. 2004. Resolução RDC $\mathrm{n}^{\circ} 48$, de 16 de março de 2004. Dispõe sobre o registro de medicamentos fitoterápicos. Diário Oficial da União, 18 mar. 2004.

Bukatsch, F. 1972. Bermerkungen zur Doppelfarbung Astrablau-Safranin. Mikrokosmos 61: 255.

Caponetti, J. D. \& M. W. Quimby. 1956. The comparative anatomy of certain species of Smilax. J. Am. Pharm. Assoc. 45: 691696.

Cheadle, V. I. 1942. The occurrence and types of vessels in the various organs of the plant in the monocotyledoneae. Am. J. Bot. 29: 441-450.

Considine, J. A. \& R. B. Knox. 1979. Development and histochemistry of the cells, cell walls, and cuticle of the dermal system of fruit of the grape, Vitis vinifera L. Protoplasma 99: 347-365.

Cunha, N. S. 1937. Da salsaparrilha a japecanga. Trib. Farm. 5:145-150.

Demason, D. A. 1980. Localization of cell division activity in the primary thickening meristem in Allium cepa L. Am. J. Bot. 67: 393-399.

Demason, D. A. 1983. The primary thickening meristem: definition and function in monocotyledons. Am. J. Bot. 70: 955-962.

Ervin, E. L. \& R. F. Evert. 1967. Aspects of sieve element ontogeny and structure in Smilax rotundifolia. Bot. Gaz. 128:138-144.

Esau, K. 1977. Anatomy of seed plants, 2nd ed. John Wiley and Sons, New York, $550 \mathrm{p}$.

Evert, R. F. 2006. Esau's plant anatomy. Meristems, cells, and tissues of the plant body: their structure, function, and development. 3rd ed., John Wiley and Sons, New Jersey, 601 p. 
Fahn, A. 1978. Anatomia vegetal. H. Blume, Madrid, 643 p.

Fontenelle, J. B., C. G. Costa \& R. D. Machado. 1994. Foliar anatomy and micromorphology of eleven species of Eugenia L. (Myrtaceae). Bot. J. Linn. Soc. 115: 111-133.

Font Quer, P. 1985. Diccionario de Botánica. Labor, Barcelona, 1244 p.

Gerrits P. O. \& L. Smid. 1983. A new, less toxic polymerization system for the embedding of soft tissues in glycol methacrilate and subsequent preparing of serial sections. J. Microsc. 132: 81-85.

Guaglianone, R. \& S. Gattuso. 1991. Estúdios taxonômicos sobre el gênero Smilax (Smilacaceae) I. Bol. Soc. Argent. Bot. 27: 105-129.

Guimarães, A. R., C. G. Costa \& R. H. P. Andreata. 2010a. Morfoanatomia do sistema subterrâneo de Smilax subsessiliflora Duham. (Smilacaceae). Rodriguesia 61: 181-194.

Guimarães, A. R., R. H. P. Andreata, A. O. Dias Neto \& M. H. D. A. Monteiro. 2010b. Anatomia foliar de espécies brasileiras de Smilax L.: S. quinquenervia Vell, S. Stenophylla A.DC. e S. subsessiliflora Duham. Rev. Agroneg. Meio Amb. 3: 77-87.

Haberlandt, G. 1928. Physiological plant anatomy. McMillan, London, 777 p.

Heywood, V. H. 1978. Flowering plants of the world. University Press, Oxford, 336 p.

Hoehne, W. 1955. Primeira contribuição à revisão das espécies botânicas incluídas na farmacopéia brasileira - II. An. Fac. Farm. Odontol. Univ. S. Paulo 12: 17-62.

Horridge, G. A. \& S. L. Tamm. 1969. Critical point drying for scanning electron microscopy study of ciliary motion. Science 163: 817-818.

Jensen, W. A. 1962. Botanical histochemistry: principle and practice. W. H. Freeman, San Francisco, 408 p.

Joffily, A. \& R. C. Vieira. 2005. Anatomia foliar de Maytenus Mol. emend Mol. (Celastraceae), ocorrente no Estado do Rio de Janeiro, Brasil. Acta Bot. Bras. 19: 549-561.
Joffily, A. \& R. C. Vieira. 2010. Cork-warts on the leaf epidermis of four genera of Celastroidea-Celastraceae. Flora - Morphol., Distrib., Funct. Ecol. Plants 205: 313-318.

Johansen, D. A. 1940. Plant microtechnique. McGraw-Hill, New York, 523 p.

Judd, W. S., C. S. Capbell, E. A. Kellogg, P. F. Stevens \& M. J. Donoghue. 2002. Plant systematics: a phylogenetic approach. 2nd ed., Sinauer Associates, Sunderland, $576 \mathrm{p}$.

Judd, W. S., C. S. Capbell, E. A. Kellogg, P. F. Stevens \& M. J. Donoghue. 2009. Sistemática vegetal: um enfoque filogenético. $3^{\mathrm{a}}$ ed., Artmed, Porto Alegre, 632 p.

Marquete, O. \& R. G. Pontes. 1994. Estudo anatômico foliar comparativo de Smilax spicata Vell., Smilax rufescens Griseb. e Smilax fluminensis Steudel. Rev. Bras. Biol. 54: 413-426.

Martin, B. F. \& S. C. Tucker. 1985. Developmental studies in Smilax (Liliaceae) I. Organography and the shoot apex. Am. J. Bot. 72:66-74.

Martins, A. R. \& B. Appezzato-Da-Glória. 2006. Morfoanatomia de órgãos vegetativos de Smilax polyantha Griseb. (Smilacaceae). Rev. Bras. Bot. 29: 555-567.

Menezes, N. L., D. C. Silva, R. C. O. Arruda, G. F. Melo-de-Pinna, V. A. Cardoso, N. M. Castro, V. L. Scatena \& E. ScreminDias. 2005. Meristematic activity of the endodermis and the pericycle in the primary thickening in monocotyledons. Considerations on the "PTM". An. Acad. Bras. Ciênc. 77: 259-274.

Metcalfe, C. R. \& L. Chalk. 1950. Anatomy of the dicotyledons: leaves, stem and wood in relation to taxonomy with notes on economic uses. Clarendon Press, Oxford.

Metcalfe, C. R. \& L. Chalk. 1979. Anatomy of the dicotyledons: systematic anatomy of the leaf and stem, with a brief history of the subject. Clarendon Press, Oxford.

Metcalfe, C. R. \& L. Chalk. 1983. Anatomy of the dicotyledons: wood structure and conclusion of the general introduction. Clarendon Press, Oxford. 
Morretes, B. L. \& M. Ventureli. 1985. Ocorrência de "lenticelas" em folhas de Tripodanthus acutifolius (R. \& P.) Tiegh. (Loranthaceae). Rev. Bras. Bot. 8: 157-162.

Oliveira, F., J. B. Silva, \& A. B. Rocha. 1973. Contribuição para o reconhecimento do rizoma de Smilax japecanga Grisebach. Rev. Fac. Farm. Odontol. Araraquara 7: 7-18.

Peckolt, O. 1936. Sobre a planta produtora da japecanga. Rev. Flora Med. 2: 513-517.

Prychid, C. J. \& P. J. Rudall. 1999. Calcium oxalate crystals in monocotyledons: a review of their structure and systematics. Ann. Bot. 84: 725-739.

Rudall, P. 1991. Lateral meristems and stem thickening growth in monocotyledons. Bot. Rev. 57: 150-163.

Sakai, W. S. 1973. Simple method for differential staining of paraffin embedded plant material using toluidine blue. Stain Technol. 48: 247-248.
Silva, A. A. J. 2006. Plantas bioativas. Essent. Herb. 2: 408-423.

Solereder, H. 1908. Systematic anatomy of the dicotyledons. Clarendon Press, Oxford, $643 \mathrm{p}$.

Stace, C. A. 1965. Cuticular studies as an aid to plant taxonomy. Bull. Br. Museum Nat. Hist. Bot. 4: 1-78.

Stellfeld, C. 1940. Sarçaparrilha e jupicanga. Trib. Farm. 8: 193-202.

Strasburger, E. 1924. Handbook of pratical botany. 8th ed., George Allen and Nonviirn, London, $533 \mathrm{p}$.

Uphof, J. C. T. 1962. Plant hairs, pp. 1-205. In: W. Zimmermann \& P. G. Ozenda (Eds), Encyclopedia of plant anatomy. Berlin, Gebruder Bornträger.

Van Fleet, D. S. 1942. The development and distribution of the endodermis and an associated oxidase system in monocotyledonous plants. Am. J. Bot. 29: 1-15.

Recebido em: 29/III/2011

Aceito em: 18/VIII/2011 